\title{
AN EPIPHANY \\ OF MYSTICAL SYMBOLS: JACOB OF SARUG'S MÊMRÂ 109 ON ABRAHAM AND HIS TYPES
}

\author{
RICHARD E. MCCARRON \\ DEPARTMENT OF RELIGION AND RELIGIOUS EDUCATION \\ ThE CATHOLIC UNIVERSITY OF AMERICA, WASHINGTON, D.C.
}

\section{INTRODUCTION}

Celebrated as the author of 763 metrical homilies and many other prose and poetic works, Jacob of Sarug (c. 450-520/1 CE) is a central figure of Syriac literature who is remembered as a master commentator on scripture:

The Holy Spirit revealed to him and explained all the secrets of the Holy Sciptures. This doctor became the vase of the Spirit and filled the Holy Church with his wisdom by commenting on the Sacred Scriptures. ${ }^{1}$

${ }^{1}$ As quoted by B. Boulos-Sony, "La Méthode exégétique de Jacques de Saroug," Parole de l'Orient 9 (1979-80): 67. Boulos-Sony's source is Paris

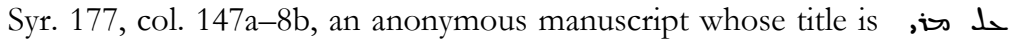

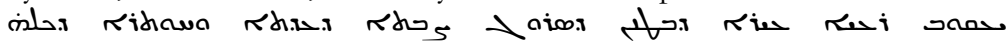
rhivals MS Paris Syr. 177 is the longer of two anonymous panegyric homilies important for their depiction of the life of Jacob. For details on the MS, see A. Vööbus, Handschriftliche Überlieferung der Memre-Dichtung des Jáqob von Serug, vol. I, Sammlungen: Die Handschriften, Corpus Scriptorum Christianorum Orientalium [hereafter CSCO] 344, subsidia 39 (Louvain: Secrétariat du CSCO, 1973) 13-6. For a recent edition of the text, see P. Krüger, "Ein zweiter anonymer memra über Jakob von Serugh," Oriens 
Jacob, bishop of Batnan in Sarug for only two years before his death, represents a generally conservative line of thinking, thus allowing the contemporary reader to appreciate the classical Syriac approach to a given topic. ${ }^{2}$ Yet, his formation in the Edessa school whose Nestorianism he came to reject, his own understanding of the Bible, and the task of biblical interpretation certainly make his work particularly his own. ${ }^{3}$ Around 470 , at about twenty years of age, Jacob was a student at the famous Edessa school of theology, which was one of the centers of christological controversy at the time. ${ }^{4}$ According to Barhadbshaba, author of the sixth-century Cause for the Founding of the Schools, the

Exegetical tradition of the school of Edessa [consists] of three elements: 1) that which follows the tradition [mashlmanutâ] of Mar Ephraem, that is that which they say was transmitted from the time of Addai the Apostle, 2) the commentary [pushäqa] of Theodore of Mopseustia and 3) the tradition [mashlmānutâ] of the school, that is, explications originally transmitted orally and inserted into the homilies and other works of Mar Narsai. ${ }^{5}$

According to Boulos-Sony, one needs as well to attend to Jacob's theological position that orients him to a more "spiritual" method of exegesis, namely the influence of Cyril of Alexandria:

His exegesis is a reaction, although he does not say so expressis verbis, against the Judaizing "textual" exegesis of the Theodorians who, according to him, had divided Christ. Jacob succeeds in uniting the Ephraemian tradition with the Alexandrian tradition in the

Christianus 56 (1972): 112-34. He follows the Syriac text with a German translation.

${ }^{2}$ For a concise overview of Jacob's life and work, including attention to the doctrinal controversies of the day, see H. R. Balz, et al. (eds.), Theologische Realenzyklopädie (Berlin: De Gruyter, 1987), s.v. "Jakob von Sarug," by Wolfgang Hage.

${ }^{3}$ See Boulos-Sony, 67-8.

${ }^{4}$ See Hage, "Jakob von Sarug."

${ }^{5}$ From J. Frishman, "Type and Reality in the Exegetical Homilies of Mar Narsai," Studia Patristica 20 (1989): 169. The original text is found in A. Scher, Mar Barhadbshabba "Arbaya.Cause de la fondation des écoles (Patrologia Orientalis IV, 4; Paris, 1907) 382-3. 
exegetical domain: finding Christ throughout the Bible. $^{6}$

For Jacob, the "center of the Bible is Christ whose two arms stretched out on the cross are symbolized by the two Testaments." 7 Jacob's christocentric stance on the Old Testament may well lead one to criticize his failure "to appreciate that narrative within its own context" because he links wondrous events across salvation history and sees the past "exclusively in connection with the working of the image of Christ." ${ }^{8}$ However, close analysis of his homilies leads one to perceive a very dynamic sense of typology, symbol, and poesis that Jacob employs to comment on the scriptures. Nowhere is such skillfull commentary more operative than in his mêmrâ 109, entitled "On Abraham and his Types," an extended exposition on the searing narrative of Genesis 22:1-14. ${ }^{9}$ After preliminary consideration of the genre the mêmrâ, this essay will analyze the content of the homily with an eye to developing Jacob's dynamic vision of symbolic interplay in salvation history.

\section{THE TeXT}

As Mary Gerhart argues, an understanding of genre is requisite to the interpretation of any text: textual meaning is always "genrebound." 10 Sebastian Brock has examined the wide body of authored and anoymous Syriac poetry of the fifth and sixth centuries and has developed a five-fold taxonomy of the narrative poems. ${ }^{11}$ Following his taxonomy, mêmrâ 109 exhibits the genric qualities of type $\mathrm{V}$ :

${ }^{6}$ Boulos-Sony, 90.

${ }^{7}$ Boulos-Sony, 68.

${ }^{8}$ Frishman, $172 ; 175$.

9 Text in P. Bedjan, Homilae selectae Mar-Jacobi Sarugensis, Vol. IV (Leipzig: Harrassowitz, 1908) 61-103. With regard to the biblical text he commented on, Jacob used the Peshitta and probably the Diatessaron. See Boulos-Sony, 68-70.

10 See M. Gerhart, "Generic Competence in Biblical Hermeneutics," Semeia 43 (1988): 29-44.

11 S. Brock, "Dramatic Dialogue Poems," in H. J. W. Drijvers (ed.), IV Symposium Syriacum 1984 (Orientalia Christiana Analecta 229; Rome: PIO Press, 1987) 135-47. 
The fifth type is characterized by the introduction into the dramatized narrative of homiletic material, where the author may offer moralizing or exegetical comment, or he may himself address one of the characters directly (apostrophe). ${ }^{12}$

This genre of mêmrâ builds upon other forms: it takes the biblical topic and retells the story in a narrative frame with speeches on the part of the characters in question introduced. To this, a type $\mathrm{V}$ adds specifically homiletic material.

The actual Sitz-im-Leben of the mêmrâ is not immediately apparent. Was it actually "preached" in a cathedral or in an ecclesial liturgical setting? Does the mêmrâ derive from Jacob's monastic milieu and the cursus of daily prayer? ${ }^{23}$ Is it a transcription of an oral address by Jacob or the later work of monk-copyists? According to biographers, "a large staff of scribes and copyists engaged in securing [Jacob's] poetic production was put at his disposal." 14 Rilliet's study of the rhetoric of Jacob's prose homilies would lead one to conclude that the homily in verse with biblical exposition would more than likely have been "preached" at less festive times of the liturgical cycle. ${ }^{15}$ Subsequent witness reveals

\section{Brock, 137.}

13 On the development of the office in the Syriac-speaking churches, see R. Taft, The Liturgy of the Hours in East and West (Collegeville: Liturgical Press, 1986) 225-37. Vööbus asserts that the mêmrê eventually did make their way into the "cells of solitaries, ascetics, mourners and monks" (122). On the early history of the office of the Syriac-speaking churches, see J. Mateos, Lelya-șapra: Les offices chaldéens de la nuit et du matin (Orientalia Christiana Analecta 156; Rome: PIO Press, 1976²).

14 A.Vööbus, History of Asceticism in the Syrian Orient: A Contribution to the History of Culture in the Near East III (CSCO 500, subsidia 81; Leuven: Peeters, 1988) 119.

15 F. Rilliet, "Rhétorique et style à l'époque de Jacques de Saroug," IV Symposium Syriacum 1984 (Orientalia Christiana Analecta 229; Rome: PIO Press, 1987) 293. "Pour les deux plus grandes fêtes, Noël et Pâques, il prefère un genre plus "arétalogique» et parénétique, tandis que pour les autres fêtes c'est le commentaire biblique et l'explication des symboles qui constituent le principal, mêmes s'ils sont encadrés assez artificiellement par un exorde et un épilogue." 
that the mêmrê found their way into liturgical books, such as homilaries, church handbooks, and choral books. ${ }^{16}$

The question of whether the textus receptus reflects a compilation of smaller homilies on similar themes can legitimately be raised. A collection of forty-seven mêmrê ascribed to Jacob found in MS Mingana 546 contains an unpublished homily entitled, "A mêmrâ of Mar Jacob on Abraham and Isaac." 17 A comparison of the text of this manuscript and the text of mêmrâ 109 of Bedjan reveals three points for consideration. First, certain sections are identical, apart from minor textual variants. Second, some sections reflect a pastiche of some sections. Third, the bulk of exegetical commentary found in early sections of 109 follows the narrative material of the short homily, which takes up Genesis 22:1-14 verse for verse, then develops the exegetical commentary. It seems likely that the Mingana text is a shortened version of 109. Given the nature of the twelve-syllable line that characterizes Jacob's poetry, one can postulate that it would be rather easy to insert and remove lines. However, any conclusion without consideration of the whole manuscript tradition would be premature. A close reading of 109 shows certain inconsistencies of word choice and juxtapositions of significant terms in the homily. For example, pkar and qtal for what Abraham is called to do; sakinâ and harbâ for the instrument, the juxtaposition of 'emrâ and dekrâ, and several words for offering or sacrifice, including 'lätâ, qûrbañâ, debhâa, and yaqdâ. Other homilies roughly contemporary with 109 on Genesis 22 do not take the same approach as Jacob, but do show the popularity of the figures of Abraham and Isaac. ${ }^{18}$ In fact, Jacob may well have known some

16 See Vööbus, Handscbriftliche, 21. "Der Memre-Dichtung war eine sehr grosse Zukunft vorgesehen, nämlich den Bereich des Kults und der Liturgie zu erobern."

${ }^{17}$ Fols. 72v to 75v; See A. Mingana, Catalogue of The Mingana Collection of Manuscripts, vol. I, Syriac and Garshuni Manuscripts (Cambridge: W. Heffer and Sons, Ltd., 1933).

${ }^{18}$ See the anonymous sôgitâ, probably from the fifth or sixth century, edited by B. Kirschner, "Alfabetische Akrosticha in der syrischen Kirchenpoesie," Oriens Christianus 6 (1906): 44-69. See also the collection of anonymous homilies by Brock wherein one can find other homilies on Abraham (and Isaac), roughly contemporary with mêmrâ 109 in Eight Syriac Mimre on Biblical Themes (Netherlands: Bar-Hebraeus Verlag, 1993). See also the English translation of sogitha by S. P. Brock, "Syriac Poetry on biblical themes, 2. A dialogue poem on the sacrifice of Isaac (Genesis 
of these mêmrê, but "in the case of a skilled poet like Jacob any direct quotation of a source is not to be expected."19

The mêmrâ is written in thirty sections of irregular length, composed of couplets of twelve syllables each. The twelve-syllable form is reputed to have been created by Jacob himself; in constrast to the seven-syllable form, his new form "allowed for an amplitude which" was in line with his poetical aims: a dignified and almost dispassionate approach to the doctrinal controversies of the day. ${ }^{20}$ It begins with an exordium addressed to Jesus and ends with a very short epilogue. The narrative frame has the following shape: ${ }^{21}$

EXORDIUM: "Abraham longed to see my day; he saw it and rejoiced" [n 8:56]

Section 1 (62.6-63.2): The story of Isaac will be told (Genesis 22:1-14)

Section 2-5 (63.3-68.20): Gn 22:1-2 Abraham's reaction and God's consolation

Section 6 (68.21-70.11) Abraham does not inform Sarah

Section 7-12 (70.12-79.14) Gn 22:3-4 The Three days' travel/conversation between Isaac and Abraham

22)," The Harp: A Journal of Syriac and Oriental Studies (Kottayam) 7 (1994): 55-72.

${ }^{19}$ S. Brock, "Two Syriac Verse Homilies on the Binding of Isaac," Le Muséon 99 (1986): 91. Brock identifies certain parallel themes between the second homily that he analyzes and Jacob's homily on Abraham and his types.

${ }^{20}$ Vööbus, History, 120. It is the MS Paris Syr 177, fol $151 \mathrm{~b}$, that Vööbus cites. According to Vööbus, Jacob's surprisingly "calm and dignified" stance was something that irked his contemporaries. Cf. History, 121. Vööbus explains with regard to the influence of the controversies of the day that, "Die christologische Einstellung des Verfassers kommt nur sehr selten zum Ausdruck. Damit ist es gesagt, dass die Memre seines Schaffens allein nur zur Erbauung der Gläubigen dienen sollten. Man spürt auf Schritt und Tritt wie er dieses Vorhaben ernst genommen hat" (Handschriftliche, 19). On the often perceived monotony of Jacob's verse form, see Vööbus, Handschriftliche, 18-9, who considers it as part of Jacob's extraordinary talents.

${ }^{21}$ For the text in question see Gn 22:1-14 in The Old Testament in Syriac according to the Peshitta Version, ed. Peshitta Institute Leiden, Part I, Fascicle I: Genesis to Exodus (Leiden: Brill, 1977). The references here to the text in Bedjan are to page and line. 
Section 13 (79.15-81.4) Gn 22:5 The youths remain

Section 14 (81.5-82.16) Gn 22:6 The wood on Isaac's shoulders

Section 15-17 (82.17-85.13) Gn 22:7: Where is the lamb?

Section 17-19 (85.14-89.19) Gn 22:8:The Lord will provide!

Section 20 (89.20-91.7) Gn 22:9 Building of the altar

Section 21-27 (91.8-99.3) Gn 22:10 Abraham raises the knife to kill

Section 27-28 (99.4-101.16) Gn 22:11-12 Do not offer him!

Section 29 (101.17-103.4) Gn 22:13-14 Ram caught in bush

CONCLUSION Section 30 (103.5-13) "Abraham longed to see my day; he saw it and rejoiced" [n 8:56 ${ }^{22}$

This mêmrâ takes the gospel text John 8:56 as its point of departure, appealing to the narrative of the testing of Abraham (nesyôneh d' abrähäm) as the foundational narrative for explication. It is important to note that title found in the Syriac as the trial or testing of Abraham orients the audience to one particular line of interpretation of the text of Genesis 22, namely one that places emphasis on the figure and agency of Abraham. The older dominant tradition, that of the "binding" or sacrifice (aqedab) of Isaac, places emphasis on the figure of Isaac and the role of sacrifice in atonement and redemption. ${ }^{23} \mathrm{Jacob}$ seems aware of both traditions, for, as Brock notes, Jacob approximates these earlier Jewish concerns about Isaac's willing acceptance of being a

22 The Syriac text reads: swo rwo Jn 8:56 in Ktabê qadishê (New York: United Bible Society, 1979).

23 See G. Vermes, Scripture and Tradition in Judaism (Leiden: E. J. Brill, 19732) 193-218. Vermes' essay is a careful study of the Jewish exegesis and theology of Genesis 22 and its impact on Christian doctrine. For the "history of readings" of Genesis 22 in the Syriac tradition see S. Brock, "Genesis 22 in the Syriac Tradition," in Mélanges Dominique Barthélemy, Orbis Biblicus et Orientalis 38 (Fribourg: Editions Universitaires, 1981), 1-30. For a summary of Greek and Latin patristic commentators, see the introductory chapters of J. Swetnam, Jesus and Isaac: A Study of the Epistle to the Hebrews in Light of the Aqedah (Analecta Biblica 94; Rome: Biblical Institute Press, 1981). 
victim and his as though in reality shedding of blood. ${ }^{24}$ Yet, the figure of Abraham is also crucial for Jacob.

\section{Exordium}

[11] Jacob's exegetical orientation and method of development of his homily are expounded in the exordium of the homily. Invoking upon the "Son of God," Jacob names Jesus' passion as the story that calls him. He alludes to John 8:56, where Abraham's joy is linked to seeing the day of salvation. Jacob will set out to demonstrate that indeed it is possible that Abraham saw the day of the Lord and rejoiced. The crux of Jacob's interpretation lies in the blazing beauty of the mystical symbols that kindled Abraham's mind. Abraham saw the "day" depicted by mystical symbols in the lamb. ${ }^{25}$ Already the audience is prepared for highly dynamic role that the rāâ, or "mystical symbol" will play in the Abraham narrative. ${ }^{26}$ Interestingly, in the exordium it is in the lamb ('emrâ) or the ram (dekrâ) whereby Abraham sees Jesus, not in Isaac as he explains in section 1. Thus, one could see the likelihood that the exordium was added onto the rest of the mêmrâ.

\section{Section 1}

[12] Here, Jacob addresses his audience, insisting that it is in the story of Isaac that one learns how Abraham saw Jesus' day. He explains that in the very telling of the story now the mystical symbol will be active once again in an "epiphany." $27 \mathrm{He}$ indicates that the key to

\footnotetext{
24 See Brock, "Genesis 22," 19.

חح: dam אa.90 (p. 61, 1. 9 and p. 62, 11. 5-6).

${ }^{26}$ For a sense of the importance of the word räqa in the Syriac world and thinking, see the significant article by E. Beck, "Symbolum-Mysterium bei Aphraat und Ephräm," Oriens Christianus 42 (1958): 19-40. I am rendering the term in English as "mystical symbol" as a way of capturing the sense of "mystery," "symbol," "secret" or even "sacrament" that are in its semantic range. See L. Costaz (ed.), Dictionnaire Syriaque-Français / Syriac-English Dictionary / Qamus suryani "arabi (Beirut: Imprimerie catholique, 1963), s.v. "rāz" and "rāzâ."

27 ph o

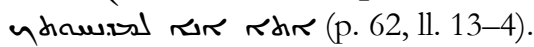


his interpretation is the use of the device of the räzâ, which will come to be demonstrated.

\section{Section 2-5}

[13] Jacob begins with the injunction of the Lord to Abraham to take his son and sacrifice $(d b h)$ him. In the Peshitta text, Isaac is called the îhîdajyâ, or "only one." The term îhîdayâ has significant christological and spiritual meanings. ${ }^{28}$ As the Syriac equivalent for ho monogenes and a frequent title of Christ, it would trigger many associations between Christ and Isaac for the audience. Jacob explains that it is primarily the Lord with whom he is concerned in this homily. Isaac is his shadow (teläleh). Immediately, Jacob dispels the horror of the command by explaining that the Lord asked for the boy's killing not that he would be killed by his parent, but that the great murder of the Son of God would be shown forth in the mystical symbol. It is not for a test of Abraham, because the Lord already knew well of Abraham's faith and love. God commanded Abraham to kill Isaac that Abraham would "depict a type of the Only One [namely, Christ] ... and would bring joy to the Old Man (säbâ) by means of the day of his crucifixion." 29 This was how Abraham could see it and rejoice. Usually a title of reverence, säbâ appears typically in monastic texts. ${ }^{30}$ Applied to Abraham it extends both the monastic connotations to Abraham and the insight of Abraham to the monastic, appropriate for Jacob's milieu.

Jacob points out to his readers that Abraham did not question or delay setting out by stopping to call God into account for his request. Jacob's descriptions employ words commonly associated at

${ }^{28}$ See S. Griffith, "Singles in God's Service: Thoughts on the îhîdayyê from the Works of Aphrahat and Ephraem the Syrian," The Harp 4 (1991): 145-59; idem, "Monks, "Singles", and the "Sons of the Covenant". Reflections on Syriac Ascetic Terminology," in E. Carr, et. al. (ed.), EULOGEMA: Studies in Honor of Robert Taft, S.J. (Analecta liturgica 17 =Studia Anselmiana 110; Rome: Sant'Anselmo, 1993) 141-60.

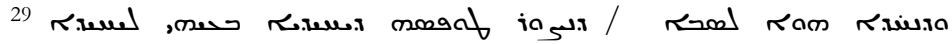
mbraraix (p. 64, 1l. 6-7).

30 For example, Ephraem uses the term in his hymn to Abraham Kidunaya; see Hymn IV, verse 1 in E. Beck (ed.), Des heiligen Ephraem des Syrers Hymnen auf Abrabam Kidunaya und Julianos Saba (CSCO 322; Louvain: Peeters, 1972) 9. See also S. Griffith, "Julian Saba, 'Father of the Monks' of Syria," Journal of Early Christian Studies 2 (1994): 208-9. 
the time with inquiries in the instance of theological inquiry or controversy: $d r r^{\prime}$, $q q b$ and $s^{\prime} e l$. In the context of his homily, Jacob is able to touch on the burning issue of the day of the correct way to do theology. Not only are there those who teach falsely, but the method that the unorthodox use is mistaken. Echoing the Ephraemian tradition, Jacob emphasizes the revelation of God and the teaching of the scriptures as the point of departure, rather than the power of the human mind. Such academic inquiry is impertinent. ${ }^{31}$ One does not stop to ask questions about what is clearly revealed by God, but like Abraham would respond with joy to God. There was no hesitation on the part of Abraham who loved and trusted God and God's promises to him. Jacob creatively develops a dramatic dialogue between God and Abraham to emphasize his point: God asks Abraham to imitate him (section 5). He enjoins Abraham not to be sad and to rejoice that God will bind God's Son at the appropriate time.

\section{Section 6}

[15] Jacob then informs his listeners why Abraham would not have told Sarah, Isaac's mother, where he was going and why. Abraham hastened and did not want to be held back by Sarah's mourning for her beloved. He made her a "stranger" to the mystical symbol, because he feared that she would protest and keep him from the so very important task he had: the showing forth of the mystical symbol. 32

31 See Ephraem's Hymn on Faith 47, 8, and 10, for example. Text in E. Beck (ed.), Des heiligen Ephraem des Syrers Hymnen de Fide (CSCO 154; Louvain: Imprimerie Orientaliste, 1955) 151; 33; 49. On the negative connotation of the words in Ephraem and a comparison with a contemporary of Jacob, Narsai, see T. Jansma, "Narsai and Ephraem: Some Observations on Narsai's Homilies on Creation and Ephraem's Hymns on Faith," Parole de l'Orient 1 (1970): 49-68, esp. appendix I.

32 On the Syriac tradition's attention to Sarah in Gn 22, see S. Brock, "Genesis 22: Where was Sarah?" The Expository Times 96 (1984): 14-7, and "Sarah and the Akedah," Le Muséon 87 (1974): 67-77. In "Two Syriac Verse Homilies," Brock provocatively raises the possibility of a woman author for a mêmrâ that give Sarah such prominent position (p. 99). From a feminist perspective, see P. Trible, "Genesis 22: The Sacrifice of Sarah," in J. Rosenblatt and J. Sitterson, Jr. (eds.), "Not in Heaven": Coherence and Complexity in Biblical Narrative (Bloomington: Indiana University Press, 


\section{Section 7-12}

[16] Without delay, Abraham set out on his way and was led by the mystical symbol on a three days' journey. Jacob describes the three days of Isaac and his "resurrection" in terms of Christ's days in the tomb and third-day resurrection. While the biblical text is silent, Jacob indicates that Isaac chattered all along the way, trying to ascertain what is going on, where and why they are travelling.

Jacob explains how Abraham knew that was the mountain he was to ascend: the sign of the Son beckoned him; the mystical symbol gestured to him to ascend. ${ }^{33}$ Abraham, the "captain of mystical symbols" (malāh rärệ) is urged to guide his ship to the port where he will find treasures. He is the "painter" (șayärâ) who will paint the image (șalmâa) of Jesus with "divine colors" (gawnê alähäyê). The mountain is named "Golgotha" and Abraham knows that he is to stop there because of "the eye of prophecy." His task on the mountain is described with ritual language: "that the mystical symbol would be correctly served on the mountain of the crucifixion." 34 Section 12 emphasizes Abraham's haste by offering postulations as to why Abraham would not have taken any companions with him.

\section{Section 13}

[18] His mind and sight captivated by the dazzingly mystical symbol that drew him to the mountain, Abraham could not turn from his way. Jacob describes Abraham's reaction in the language of a mystic experience: being on fire with love and inebriated with the wine of Golgotha. He asks the youths to stay behind and wait for him. Jacob indicates that Abraham perhaps edified them by the hope that came from his knowing that both he and Isaac would

1991) 170-91. Trible does not refer to any Syriac texts. However, Jacob, among other Syriac writers, has a place for Sarah in the unfolding of the narrative in his homily, although Sarah is still in the end relegated to a nonclimactic role, as Trible might observe.

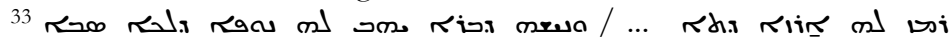

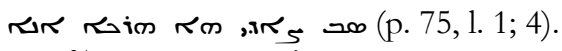

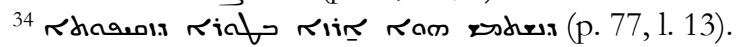


return from the top of the mountain. Again, he did not become weak, but ritually served love. ${ }^{35}$

\section{Section 14}

[19] On the way up the mountain, Isaac is given the wood to carry on his shoulders, while Abraham carries the other items needed. In this way, the image of the Son of God, carrying the cross himself to Golgotha would be shown forth. Isaac put on a coat of mystical symbols and shone with beauty as he walked on the way to his killing.

\section{Section 15-17}

[20] The next sections are Jacob's poetic expounding on verse 7 of the Genesis text. ${ }^{36}$ Jacob first takes up Isaac's calling out "Father" to Abraham. Herein he sees "the duty of a parent" and the relationship of the child played out. Like a wise one, Isaac then poses his question: "Where is the lamb?" He sees no lamb, sheep, ram or bull for sacrifice, but Abraham still caries the knife and the flame, while Isaac has the kindling. Isaac "boiled over with expressions full of passion." 37 Abraham, however, did not flinch. He did not allow himself to become sad nor put off the task of the killing. He is "drunk" with love and did not weep bitterly at the perceptive questions asked by his îhîdāyâ or "only one." Jacob exhorts his audience to see in Isaac the image (șurtâ) of Jesus. He makes allusion to Jesus' abandonment to the will of the Father: "Not my will but yours" ( $\mathrm{Lk} 22: 42 \mathrm{~b})$.

\section{Section 17-19}

[21] With steadfastness that Jacob parallels to Jesus' obedience, Abraham answers Isaac's question in verse 8 of the text: "God will

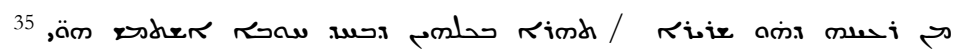

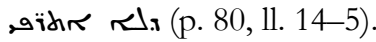

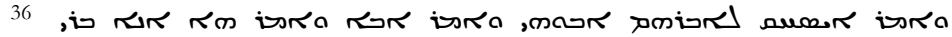

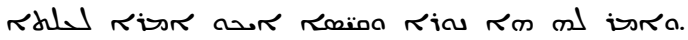

37 (p. 85, 1. 14).
} 
provide for [lit. will see to] the lamb for the sacrifice, my Son. ... "38 Jacob asserts:

For if it were not with the mystical symbol of the Son that Isaac was clothed / in what time would Abraham see the day of the Son? / How did he fix his eyes and see the crucifixion? / Except if on his son it was drawn mystically / when and where was he glad in the Messiah or how / Except in that type that was drawn on his only one. ${ }^{39}$

One can perceive again the play on term, îhîdāyâ, juxtaposing Isaac and Jesus. In section 19, Abraham lets Isaac know that God's task is to provide; what Isaac's part will be he will see. Abraham placed it all in the Lord's hands, and Isaac willingly accepted.

\section{Section 20}

[23] Having arrived at the spot on the mountain, Abraham sets about building the altar for the holocaust. He knew the spot because the "visible glory of the mystical symbols" (skkintâ dräzế) dwelt there. Abraham is likened to the master builder who carefully lays out the stones for the "house of mystical symbols" (baytâ dräzê) wherein the altar would be built. Isaac helps him, according to Jacob, which causes him to exclaim: "Who has ever seen a lamb who builds the altar for his killing!" 40

\section{Section 21-27}

[24] At the prompting of the mystical symbol, Abraham prepares to raise his knife and kill his son. Jacob emphasizes the action of the mystical symbol. The räâa is not static, but is an important agent in the unfolding of the story. Isaac notes that everything is ready, but there is still no lamb. In Jacob's reconstrual of the story, Isaac then tells his father that he will willingly accept whatever it is his father will do to him. Jacob insists that it would have been easy for the

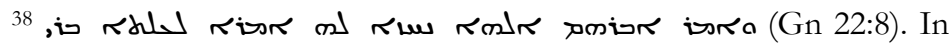
the mêmrâ, Jacob calls God "märyâ."

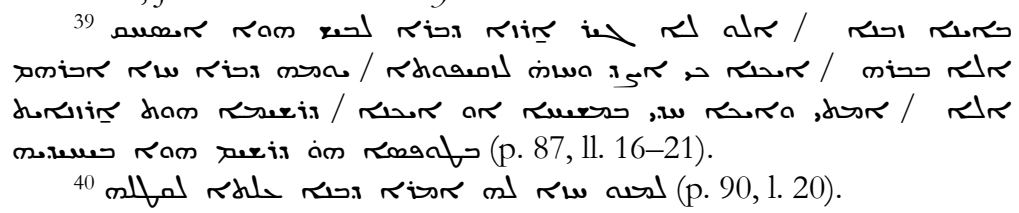


youth to flee, but he does not. Rather, Isaac is a rational youth, intelligent and excellent in speech; he is a brave one ready for sacrifice. He feared no harm, so he did not hold back. Like a necklace he wore the mystical symbols so that he could show forth the image (yuqnâ) of Jesus. He stretched out his throat while he rejoiced. Abraham knew because of the mystical symbol that Isaac was to be the lamb, and Isaac freely held out his hands to be bound.

Having bound him and placed him on top of the wood, Abraham lets Isaac know what is to happen: "It is right that you rejoice since behold I have given you as a sacrifice to the Lord." 41 As he lowers Isaac's head under the knife, Abraham tastes and smells a sweetness and sees not gloom, but life. Abraham's mind works faster than his deeds: for in his mind, Isaac is already killed and the colors of the mystical symbol shine forth for him.

\section{Section $27-28$}

[26] Just as Abraham is to lower the knife, he hears the twofold call of his name, and he took away the sword from Isaac without his being wounded. God calls Abraham that he not continue with his sacrifice. God tells Abraham that it would be senseless to kill Isaac because his blood does not save. Rather, because Abraham so desired it, God showed him the mirror of mystical symbols that he might see what God would do by Jesus's death. ${ }^{42}$ God says to Abraham:

The shadow is given to you that you would see the type / Rejoice in the image and observe the equivalence to that which is his. ${ }^{43}$

It is Christ the Strong One (hasinâa) who will shatter the fetters of hell and destroy Hades.

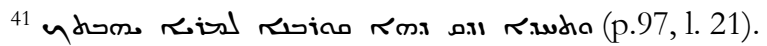

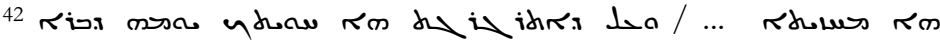
(m. 100,1.19; p. 101, 1. 1). On the rich term malhzitâ, see E. Beck, "Das Bild vom Spiegel bei Ephräm," Orientalia Christiana Periodica 19 (1953): 5-24.

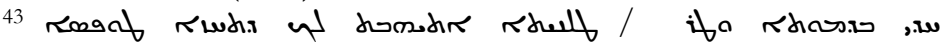

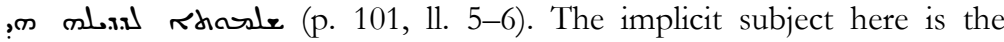
kingdom (Gen 49:10). See T. Jansma, "Ephrem on Genesis XLIX 10," Parole de l'Orient 4 (1973): 247-56.
} 


\section{Section 29}

[28] Jacob begins the next to last section with a summary of the point of his exegesis:

Abraham rejoiced in the day of the Son that he saw in his son / And he understood in the whole matter the reason of the crucifixion / The hidden mystical symbols were explained to him in the sacrifice of his son / And by means of the figures that happen there he came to an insight. ${ }^{44}$

[29] Jacob finishes out his explication of the text with verses 13-14 of the Genesis text that tells of Abraham's spying a ram caught in a bush nearby that he offers to God. Isaac's dialogue tells the audience that indeed there was nothing around before, but now there is the miraculous appearance of the ram. In Jacob's imagination, the ram is another of the figures or signs whereby Abraham sees the day of Jesus. For Jacob, the miraculous appearance of the ram reveals God's salvation in Jesus: his conception, birth, passion, death and resurrection. Jacob exhorts Abraham, "If you wish to see his birth look out at the tree / And if also his death and his sacrifice, behold it is before you!" 45

\section{Section 30}

[30] The concluding section notes that the binding of Isaac made a proclamation to the world about its salvation. In place of Isaac, Abraham bound and killed the ram, which itself depicted the pasch of Christ. The mêmrâ ends with a blessing of the passion of the Only One (î̉îdayyâ), Jesus, at whose day Abraham rejoiced.

\section{The Mystical Symbols}

This analysis of Jacob's mêmrâ on Abraham and his types reveals that Jacob has a dynamic understanding of the figure of Abraham and Isaac in salvation history. Typically, this mode of exegesis is identified as typological. Typology is generally defined as

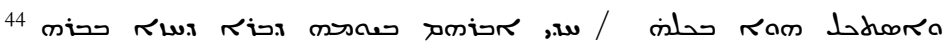

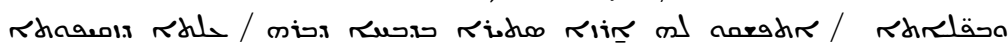

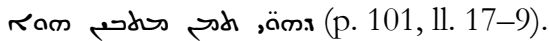

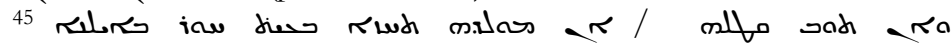
ח (p. 102, 1l. 8-9). 
an exegetical strategy that interprets all of history "in light of its fulfillment in Christ ... shadows of New Testament truth in Old Testament events." 46 But to consider Jacob's analysis solely in terms of the standard type-antitype relationship misses Jacob's complex poetic contribution. Indeed, while typology as ordinarily understood is considered out-moded by modern biblical scholars given to the historical-critical methods, one should note that "typology incorporates the old into the new and thereby helps to constitute a tradition." 47 It may be seen to serve as a means of discourse that enables a participation "in history's eschatological truth." 48 As is apparent from his homily on Abraham and his types, for Jacob there is an eschatological experience of history that can be expressed by means of the metaphor of "shadow." Yet, something more is transpiring in the case of the binding of Isaac. The key is the function of the rāâ, or mystical symbol. ${ }^{49}$

The räza is an active agent in the narrative of salvation history in a way that seems to interlink past, present, and future. It is not so much a "discombobulation of the text by time as the enhancement of a text by time" that allows a reading of greater scrutiny and awareness. ${ }^{50}$ The mystical symbol is not a static image or thing. Rather, it is constantly acting in an almost personified way throughout the course of the narrative, in its configuration in Christ and in its epiphany in the homily. Jacob is faced with the same temporal conundrum that the audience of Jesus perceived in Jesus' assertion that Abraham longed to see his day, saw it, and rejoiced. The audience of Jesus according to the Johannine text

46 J. Kee, "Typology and Tradition: Refiguring the Bible in Milton's Paradise Lost," Semeia 51 (1990): 155.

${ }^{47} \mathrm{Kee}, 156$. For a summary of the negative view of typology, see R. E. Brown, "Hermeneutics," in The New Jerome Biblical Commentary (Englewood Cliffs: Prentice Hall, 1990) 1156-7.

48 Kee, 156.

${ }^{49} \mathrm{My}$ interpretation of räzâ in Jacob's homily is far more dynamic and engaged in salvation history that that given by Boulos-Sony, 101-3. For him the rāzâ is "une image temporelle qui attendait que la réalité (qushto) le rende parfait et achevé" (103). According to Boulos-Sony, Christ eclipsed all razê by his coming.

50 R. Carroll, "Discombobulations of Time and the Diversities of Text: Notes on the Rezeptionsgeschichte of the Bible," in R. Carroll (ed.), Text as Pretext: Essays in Honor of Robert Davidson (JSOT Supplement Series, 138; Sheffield: Sheffield Academic Press, 1992) 77. 
exclaims, "You are not yet fifty years old, and have you seen Abraham?" (Jn 8:57). Abraham, for Jacob, is intimately involved in the course of salvation history and did indeed see the day of Jesus because he was led to it, informed, galvanized, and instructed by the mystical symbol. The räzâ inflamed his mind and shone forth in his actions.

From Jacob's christocentric point of view it is indeed an event of salvation history that Abraham's wise following of the mystical symbol brings about. The räzâ breaks linear time: what matters for Jacob is the story of salvation being wrought. Isaac himself at first is not under the sway of the symbol the way his father is, but gradually comes to the wise perception of the event. He did not run away for he knew that he was participating in the bringing to be of the mystic symbol that he himself wore like a neck chain. Far from a "foreshadowing" of Christ, Abraham actually sees Jesus's saving actions played out before him in his own actions and is thus a major figure in the proclamation of the salvation of the world that is yet to come: the eschatological promise his actions hold.

In terms of the present, the very same razâ is invoked by Jacob at the beginning of his homily to break forth once more in his retelling of the story. He describes the raza $a$ s function as that of epiphany. In the course of Jacob's elucidations, there comes to be the same mystical symbol that acted in Abraham's day as a prepresentation of the event of the cross where the razâ would be active again. It is important to pay close attention to the action of gesturing or of making signs (rmaz, nominal form remzâa) that is also in the range of words used to capture symbolic activity: tûpsâ, nîsâa, șurtâ, dmutâ, pel'atâ, șalmâ. In another of his homilies, Jacob speaks of Christ as working with gestures (remzê) or traces that change, destroy, and refashion, even restore a new creature. ${ }^{51}$ In the moment of Jacob's preaching, the mystical symbol is working once more, blazing or shining forth for the present listeners to see at work the traces of history that are indeed part of their tradition. They perceive once again the rāa $\hat{a} \mathrm{~s}$ brilliance and are led to a deeper love of Christ and of his passion.

The rāza is almost always referred to by means of light or visual imagery. It blazes, shines, or burns. The visible quality is part of the mystical symbol by which an invisible reality is rendered

${ }^{51}$ Cf. Alwan, 101-3 
visible. ${ }^{52}$ One sees it, looks out at it, is enticed or drawn by it. It gestures. Abraham depicts it, paints it. The mystical symbols are colorful. The pictorial languge used to describe the narrative scene and the work of the mystical symbol itself in such a way that the "presence of concrete spiritual reality" opens the way to the perception of God's activity. ${ }^{53}$ The narrative of the binding of Isaac manifests a reality with which the hearer can dwell once more. ${ }^{54}$ Jacob himself asks, "Let the mystical symbol of the Son abide in the narrative." 55 The audience is discerning and questioning; Jacob intends to let the epiphany of the mystical symbol in his preaching enlighten his demanding hearers.

Jacob's reading of the text might in fact be seen as a rather sophisticated reconstruction of the field of reality at work in the Genesis narrative through a process of gap-filling by means of the $r \bar{a} z \hat{a} .{ }^{56}$ The first gap that Jacob seeks to fill is the difficult question of why God would ask Abraham to sacrifice his son and why Abraham would respond so willingly. He imaginatively reconstructs

52 "Die Sichtbarkeit gehört zum Wesen des Symbols; aber sie erschöpft nicht ihr Wesen. Denn ebenso wesentlich ist das Wunderbare, daß in dieser Sichtbarkeit ein Unsichtbares sichtbar wird." Beck, "Symbolum-Mysterium," 28.

53 Verna Harrison, "Word as icon in Greek patristic theology," Sobornost 10,1 (1988): 40. See also S. Griffith, "The Image of the Image Maker in the Poetry of St. Ephraem the Syrian," Studia Patristica 25 (1993): 258-69, who demonstrates that Ephraem's work better exemplifies the phenomenon of iconographic language.

54 Cf. Harrison, 48. She notes the tendency to dismiss patristic exegesis because it is often characterized as "typology" or "allegory" and suggests an "iconic" reading would be the way to bridge, judge, and rehabilitate patrisitic exegesis. For a developed argument for a "theoretic" hermeneutics (in the sense of theoria or "spiritual vision") see J. Breck, The Power of the Word in the Worshipping Church (Crestwood: St Vladimir's Seminary Press, 1986) 49-92.

55 "npûsh mekêl razeh dabrâ men tashcîtâ" (p. 63, 1. 1).

56 See M. Stemberg, The Poetics of Biblical Narrative (Bloomington: Indiana University Press, 1987) 186-229. "The literary work consists of bits and fragments to be linked and pieced together in the process of reading: it establishes a system of gaps that must be filled in. This gapfilling ranges from simple linkage of elements, which the reader performs automatically, to intricate networks that are figured out consciously, laboriously, hesitantly, and with constant modifcations in light of additionally information disclosed in later stages of the reading." (186). 
a dialogue between God and Abraham and seeks to discern God's motive: it is not a question of love, faithfulness or obedience on Abraham's part, but it is done so that the mystical symbol might show forth. The state of mind of Abraham and Isaac is probed for clues when the text falls silent: what happened on the the three day journey? where was Sarah? what did Isaac think? why did Abraham not respond? what did the youths do? why did Isaac carry the wood? how did Abraham know where he was going? why did they not become sad or weep bitterly? why would Isaac call upon his father? why did Isaac not run? why did Abraham hold back the knife finally? whence the ram? For Jacob it is precisely in the gaps that he perceives the mystical symbol at work. While the narrative sets up system of gaps to "establish (and impress on the reader) a hierarchy of importance," 57 Jacob constructs a world of drama by which he is able to manifest the event character of the räza for his audience.

For Jacob, rāâ is absolutely linked to the the event of Christ's passion, death, and resurrection. The Pasch, in turn, is the axis of Jacob's reconstrual of all reality experienced. If the text is going to have the capacity to inform the present hearer, then it must be understood as disclosure of the Pasch. ${ }^{58}$ This is possible because of an epiphany of räzê. Jacob interprets within an intertextual frame whereby he finds present meaningfulness in particular narratives because they blaze with mystical symbols. Through homiletic reconstrual of the story he is able to make them shine forth once more for his hearers.

${ }^{57}$ Sternberg, 192.

58 Quite interestingly, such concerns are not far off from those of contemporary hermeneutics. For example, see H. Frei's reading of P. Ricoeur in 'The 'Literal Reading' of Biblical Narrative in the Christian Tradition: Does It Stretch or Will It Break?" in F. McConnell (ed.), The Bible and the Narrative Tradition (New York: Oxford University Press, 1986) 43-55. "One needs, finally and foremost, to have a text both atemporally distanced from its moorings in a cultural and authorial or existential past and yet also re-entering the temporal dimension at the point of the present, if it is going to have the capacity to inform an understanding that is itself essentially characterized as present, in a word, a hermeneutics of restoration" (53). Later in the same essay, Frei calls for urgent attention to midrash in the formulation of the task of Christian biblical interpretation. 
Jacob's mêmrâ on Genesis 22: 1-11 thus has a poetic function. ${ }^{59}$ The point of the mêmrâ is not an empirical description nor an exposition on the original meaning or authorial intent. Rather, it operates from a point of view that "truth no longer means verification, but manifestation, i.e., letting what shows itself be." 60 A new way of being, a proposed world of possibilities, is unfolded by the text by means of Jacob's imaginative reconstrual of the story. At the outset of the mêmrâ, he moves beyond the received interpretations of the Genesis narrative: a test of Abraham's faith by God or that God needed sacrifices. Rather, Jacob begs a closer scrutiny of the text, one that almost does require a literal reading of the text that seeks God's actions in the mystical symbols. Such a reading enables one to discern in the shadows the traces of the murder of God's Son. ${ }^{61}$ People who investigate (bahärê) can see the mystical symbol at work. Investigation is not always negative, but can be done well as long as it respects the revelation of God. Thus, the world they perceive is not one of trial or child sacrifice, but "the way of the great murder of the Son" that alone brings life to the world. ${ }^{62}$ Far from being diminished or passive, Abraham and Isaac directly participate in the revelation of this way by painting the blazing protrait of mystical symbols. It is precisely the mystical symbol that opens up this perception of the binding of Isaac and the ram caught in the tree of "how there would be salvation by the hands of our Lord" in the event of Christ's Pasch. ${ }^{63}$ For Jacob the Pasch is a central event in the economy of salvation, the mdabranntâ d'alāhâ. Because of his conception of the centrality of the Pasch in God's economy of salvation, Jacob can speak of rärê hinting and gesturing. The activity of the mystical symbol is possible because God brings it to be or allows it. Jacob reads the Genesis 22 narrative in an eschatological frame: the figures and actions of Abraham and Isaac are anticipatory of the death of Christ and what

59 See P. Ricoeur, "Toward a Hermeneutics of the Idea of Revelation," chap. in L. Mudge (ed.), Essays on Biblical Hermeneutics, (Philadelphia: Fortress, 1981) 98-110.

${ }^{60}$ Ricoeur, 102.

61 ision (p. 63, 1. 6).

62 On the significance of the metaphor of the way in Jacob's conception of soteriology, see F. Rilliet, "La métaphore du chemin dans la sotériologie de Jacques de Saroug," Studia Patristica 25 (1993): 324-31.

${ }^{63}$ is (p. 62, 1.4). 
that death brings about. For Jacob, the Pasch of Christ is the key moment, one which is integral to the whole scope of God's providence.

In mêmrâ 109, Jacob perceives the event of the sacrifice of Isaac as a prophetic situation whose ambiguity calls for explication. The historical event of the Pasch then takes on a hermeneutical function: one comes to understand and to know what has transpired in salvation history in light of the Pasch. ${ }^{64}$ When Jacob takes up the biblical text, he speaks of what God is doing and signifiying from the point of view of the salvific death and resurrection of Jesus. Jacob's interpetation itself takes on the narrative structure of the original, following the text verse by verse. For Jacob, it becomes an open frame that he imaginatively reconfigures through dramatic dialogue and explication of the mystical symbol's agency in the event. He transforms the events of the narrative in way that its meaning is manifested to his present audience. He reads from the future back rather than from the past forward. He certainly respects the particular character of the narrative that he explicates: he preserves its language, its master images, and its plot. However, his telling of the story has as its goal the present appropriation of the text, which for him can only make sense in the literally blazing light of the Pasch manifested by razêe. Such would be the "spiritual" sense of the passage, but it is only through the literal level that it can be made clear.

\section{CONCLUSION}

The mêmrâ on Abraham and his types exemplifies Jacob of Sarug's poetic artistry and dynamic understanding of the task of biblical interpretation. To dismiss Jacob's exegesis as merely typological fails to appreciate a far more dynamic strategy of narrative reconfiguration in light of the Pasch. By calling forth attention to the epiphany of mystical symbols that allow an almost ecstatic communion of past, present, and future, Jacob reveals Abraham and Isaac's important role of depicting the traces of God's decisive action in Jesus in the whole course of salvation history. Abraham's binding and near sacrifice of Isaac are not

${ }^{64}$ See Betty Rojtman, "Le récit comme interprétation (à partir de Gen. 22 et du Midrach Rabba)," Revue de théologie et de philosophie 122 (1990): 162 , on history's hermeneutical function. 
relegated to a less-than-true type of the fulfilment to come in the Pasch, but is perceived themselves as a blazing forth of the salvific action of God in an event of eschatological truth. By means of the mêmrâ genre, Jacob weaves exegetical comment, imaginative gapfilling, and dramatic dialogue in order to unfold an event. Each moment he calls attention to the agency of razzê as the means of unlocking the meaning of the text of Genesis 22:1-11. 